\title{
Eskatologiens udvikling hos den historiske Jesus
}

\author{
Professor Dr. Gerd Theissen
}

Per Bilde: Den historiske Jesus. København: Anis 2008. 336 s. Kr. 299.

Abstract: This article reviews Per Bilde's Den historiske Jesus. Three theses of Bilde are discussed: (1) The "sign prophets" in the first century C.E. are the nearest analogies to Jesus, but we should make a difference between those before the Caligula-crisis, who have been interested in cult and conversion, and those after this crisis. (2) Jesus had a messianic consciousness, but participated in a mentality that says: Nobody can legitimately give oneself a new status he can only receive it from a superior. (3) There is a development from proclaiming God's mercy to announcing God's judgement, but the interpretation of Jesus' death as atoning death seems to be a retrospective interpretation after Easter. We may therefore say: The main three theses are basically justified but they should be modified a little bit.

Key words: Per Bilde - The historical Jesus - prophets in the first century - messianic selfconsciousness - development in Jesus' proclamation

Per Bildes bog om Jesus tilhører i forskningshistorisk henseende "the third quest" efter den historiske Jesus, som ikke spørger efter det kirkelige Jesusbilledes legitimitet, men udelukkende går historisk til værks og i denne forbindelse udvikler en større tillid til Jesusoverleveringens historiske pålidelighed end den forudgående Jesusforskning. Nogle forskere inden for denne forskningsretning går ind for en ikkeeskatologisk forståelse af Jesus, men andre anser nu som før eskatologien som nøglen til en virkelig historisk forståelse af Jesus. Per Bilde tilslutter sig afgjort den eskatologiske fløj. Han underbygger eskatologiens centrale plads med tre argumenter: Jesu dåb viser, at han engang har været tilhænger af Johannes Døberen og delte Døberens nærforventning, Jesus' henrettelse ved romerne kan kun gøres forståelig, hvis han havde fremkaldt eskatologiske forventninger om en stor omvæltning, som inkluderede enden på romernes herredømme. Sammenligningen med beslægtede jødiske profetiske skikkelser i det første århundrede, blandt andet en samaritansk profet, profeten 
Theudas og en profet fra Ægypen, bekræfter hans budskabs eskatologiske præg, men fremhæver også dets enestående særpræg: Den futuriske eskatologi bliver modificeret af en præsentisk eskatologi. Ved hjælp af eksorcismer og helbredelser realiseres frelsen allerede i samtiden og hans måltider med marginaliserede mennesker foregriber det eskatologiske måltid allerede nu.

Per Bildes særlige bidrag er en teori om Jesus' udvikling. Jesus' eskatologiske forventning blev skuffet allerede i hans levetid. Den derved givne kognitive dissonans bevirkede to transformationer i Jesus' forventninger. Den krise, som henrettelsen af Johannes Døberen fremkaldte, overvandt Jesus ved at transformere Døberens budskab om dommen til et budskab om frelsen. Jesus nåede frem til en sikker overbevisning om at være den Messias, som skal introniseres i Jerusalem og bringe romernes herredømme til ende. Ved slutningen af sin virksomhed transformerede Jesus endnu engang sin eskatologi: Som reaktion på afvisningen af sit budskab blandt folket fornyede han budskabet om dommen - bl.a. ved profetien mod Jerusalem og dets tempel - og han regnede med en voldsom død, som han tolkede ved hjælp af Es 53 som en vikarierende sonedød for andre. Jesus' henrettelse på korset fremkaldte en tredje kognitiv dissonans - denne gang ikke hos Jesus, men hos disciplene: På grund af påskevisionerne og den tomme grav overvandt de korsets krise og nåede derved til den overbevisning, at Jesus ikke bliver introniseret som Messias på jorden, men i himmelen for at herske over alle kosmiske magter.

I det følgende tager jeg stilling til tre aspekter i Bildes bog om Jesus: For det første drejer det sig om hans brug af tidshistoriske analogier, for det andet om hans tese om en messiansk selvbevidsthed med en politisk dimension hos Jesus, for det tredje om hans tese om udviklingen i Jesus' eskatologi.

\section{Jødiske profeter som analogier}

Hvad angår de daværende profeter som analogier til Jesus, må vi skelne mellem nærmere og fjernere analogier, dvs. mellem de profeter, som virkede på Jesus' og Pilatus' tid: Johannes Døberen, Stefanus som Jesus' tilhænger, en anonym samaritaner på den ene side - og profeterne efter 40 e.Kr. på den anden side. Profeterne på Pilatus' tid kom med et budskab, der var vendt indad mod folket, om en omvendelse, som var nødvendig for fornyelsen af Israel. Alle profeter forholder sig kritisk til de eksisterende templer. Tempelkritik er implicit allerede i Døberens prædiken. Kun få kilometer fra templet i Jerusalem tilbød han syndsforladelse uden offer i en tid, hvor det egentlig var 
templets opgave at formidle syndforladelse gennem kultiske handlinger. Stefanus bebudede en forandring af Moses' ordninger vedr. templet gennem den kommende Jesus, sandsynligvis håbede han på templets åbning for hedningerne. En samaritansk profet forjættede ca. 35 e.Kr., at han ville finde de tempelredskaber, som Moses engang skulle have skjult på bjerget Garizim (Jos Ant 18,85). Det bliver helt anderledes hos profeterne efter Theudas (ca. 44/45 e.Kr.). De senere profeters mål er en generobring af landet, sådan som det skete i gamle Israel. Deres budskab tilbageviser de fremmedes krav på landet. Theudas vil som en erobrer gennem Jordanfloden trænge ind i landet. En profet fra Ægypten vil gentage underet fra Jeriko ved Jerusalems mure. Under krigen bestyrker andre profeter tilliden til, at Gud vil beskytte templet. Det er kun profeten Jesus ben Ananias, som 62 e.Kr. optræder med et budskab mod Jerusalem og dets tempel.

Hvorfor er proferne indtil 60'erne kun interesseret i en indre fornyelse og omvendelse, hvorimod profeterne efter 40 e.Kr. i højere grad vender sig imod fremmede? Det findes der en nærliggende forklaring på. 39/40 e.Kr. blev det jødiske folk rystet ved den store Caligulakrise. Gaius Caligula forsøgte på at forvandle Jerusalems tempel til et hedensk tempel. Efter dette kunne jøderne ikke længere regne med at blive respekteret i deres eget land. Som hovedregel kritiserede profeterne efter 40 e.Kr. ikke længere templet og deres eget folk, men i stedet de fremmede. Det har konsekvenser for vores opfattelse af Jesus. Jesus tilhørte den tidligere gruppe af profeter, dvs. de profeter, som krævede en indre omvendelse. Det passer ikke så godt sammen med en politisk messiansk selvbevidsthed.

\section{Jesu messianske selvbevidsthed}

Det fører hen til bogens anden hovedtese: Bilde regner med en messiansk selvbevidsthed hos Jesus med politiske dimensioner. Vi kan ikke drøfte hele dette meget indviklede problem her. Og det er et spørgsmål, om vi ikke hellere skulle lade dette problem stå åbent. Ifølge antik mentalitet kunne Jesus overlade, hvem han egentlig var, til Gud, for status kunne kun gives af en højerestående person, og kun en højerestående person kunne proklamere denne status offentligt. Belæg for denne form for "statuskontingens"' finder vi i samtalen med Zebedæussønnerne. De beder Jesus om at få hæderspladser-

1. Gerd Theissen, "Vom historischen Jesus zum kerygmatischen Gottessohn. Soziologische Rollenanalyse als Beitrag zum Verständnis neutestamentlicher Christologie“, EvTh 68 (2008), 285-304. 
ne ved siden af ham til højre og til venstre, og Jesus svarer: “ ... sædet ved min højre eller min venstre side står det ikke til mig at bortgive; men det gives til dem, hvem det er beredt" (Mk 10,40). Det er Gud alene, der bortgiver hæderspladserne. Hvis vi her er konsekvente, må det også gælde den plads, Jesus engang selv vil få. Spørgsmålet om tildeling af status og rang kunne Jesus derfor overlade til Gud. Man kan dog ikke ud fra Zebedæussønnerne spørgsmål slutte, at Jesus selv forventede at bliver introniseret som Messias i Jerusalem. Han taler om det himmelske måltid (cf Mt 8,11) - en kongelig intronisation er her ikke nødvendigvis forudsat. Jesus forventede derimod sine disciples intronisation. De skulle dømme Israels tolv stammer (Matt 19,28 par). Derved overføres en forventning, som ifølge SalomoSl 17,26 eksklusivt gælder Messias, til et messiansk kollektiv. Jesus korrigerer således den traditionelle monokratiske forventning til Messias ved en ny gruppemessianisme. ${ }^{2}$ Sådanne indicier for en korrektion af den traditionelle messiasforventning skal tages alvorligt. De viser, at Jesus var nødt til at gøre op med messianske forventninger. Der kan ikke være tvivl om, at han også havde fremprovokeret sådanne forventninger, hvilket dog ikke betyder, at han accepterede dem. I stedet modificerede han dem.

\section{Jesus' forkyndelses udvikling}

Den mest originale tanke i bogen er antagelsen af en udvikling i Jesus' forkyndelse med to vigtige ændringer: for det første en udvikling fra en forkyndelse af dommen, der minder om Døberens forkyndelse, til forkyndelse af frelsen. Efter adskillelsen fra Døberen bliver Jesus overbevist om, at han er Messias. For det andet drejer det sig om en udvikling fra frelsesforkyndelse til et nyt budskab om dommen: Gennem tanken om den stedfortrædende sonedød forvandles dommen til et budskab om frelse. Denne udvikling er en reaktion på afvisningen af hans budskab. Det er en fascinerende teori. Efter mit skøn er det dog muligt at adskille tesen om eskatologiens udvikling hos Jesus fra to andre teser: på den ene side tesen om hans messianske selvbevidsthed, på den anden side spørgsmålet om tolkningen af hans død som

2. Gerd Theissen, "Gruppenmessianismus. Überlegungen zum Ursprung der Kirche im Jüngerkreis Jesu", in: Gerd Theissen, Jesus als historische Gestalt. Beiträge zur Jesusforschung, red. Annette Merz, FRLANT 202 (Göttingen: Vandenhoeck \& Ruprecht 2003), 255-281 (263ff). Til dette logion og dets autenticitet se Hanna Roose, Eschatologische Mitherrschaft. Entwicklungslinien einer urchristlichen Erwartung, NTOA 54 (Göttingen/Fribourg: Vandenhoeck \& Ruprecht/Academic Press 2004). 
sonedød. Det er ikke strengt nødvendigt at forbinde tanken om en udvikling hos Jesus med de andre hypoteser.

\section{a) Jesus' udvikling fra Døbertilhanger til selvstandig forkynder} Forskellene mellem Døberens adfærd og Jesus tillader en antagelse om, at der må være sket en forandring i Jesus' eskatologi mellem den tid, da Jesus var tilhænger af Døberen og den tid, da han virkede selvstændigt. Både Døberen og Jesus udtrykte deres eskatologi vha. to agrare billeder: henholdsvis træet og dets frugt og det beslægtede billede af sæden og høsten. ${ }^{3}$ En sammenligning er oplysende. Døberen sagde (tillad mig at citere mig selv for at understrege overenstemmelsen med P. Bilde):

Die Axt ist schon an die Wurzeln der unfruchtbaren Bäume gelegt (Matt 3,10). Der Richter steht mit der Worfschaufel zur Scheidung von Spreu und Weizen bereit (Matt 3,12). Beide Bilder begegnen bei Jesus wieder, werden aber so verwendet, dass sie dem Menschen Zeit einräumen: Im Gleichnis vom unfruchtbaren Feigenbaum (Luk 13,6-9) erhält der Baum noch eine Frist. Aus der zugespitzten Zeitbegrenzung beim Täufer wird die Gewissheit von Zeitgewinn zur Umkehr. Ebenso liegt beim Bild von Saat und Ernte nicht der Akzent auf dem Gericht. Im Gleichnis von der "selbstwachsenden Saat" wird vielmehr das spontane Aufgehen und Fruchtbringen der Saat zur Pointe. Erst danach folgt die Ernte, das Gericht. Überlegenswert ist in der Tat, ob Jesus damals nicht eine erste "Parusieverzögerung" verarbeitet hat: Die Nächst-Erwartung des Täufers war nicht in Erfüllung gegangen, der Prophet war inhaftiert und getötet worden. Jeder Augenblick der weiterexistierenden Welt wird jetzt als Ausdruck der Gnade Gottes gedeutet. Gott verzögert sein Gericht, um Menschen eine Chance zur Umkehr zu geben. Schroffe Gerichtspredigt (mit dem Gnadenangebot der Taufe im letzten Augenblick) schlägt um in Gnadenpredigt mit dem Angebot zur Umkehr angesichts des drohenden Gerichts. Die bloße Existenz der Welt, schon das Aufgehen der Sonne über Guten und Bösen, kann jetzt zum Zeichen der Gottesliebe werden (Matt 5,45). ${ }^{4}$

M. Ebner har søgt at gøre denne udvikling historisk plausibel gennem følgende overvejelse. Han forudsætter en spænding mellem

3. Petra von Gemünden, Vegetationsmetaphorik im Neuen Testament und seiner Umwelt. Eine Bildfelduntersuchung, NTOA 18 (Göttingen/Fribourg: Vandenhoeck \& Ruprecht/Universitätsverlag 1993), 122ff.182ff.

4. Gerd Theissen/Annette Merz, Der historische Jesus. Ein Lehrbuch, (Göttingen: Vandenhoeck \& Ruprecht 1996, 32003), 195. Denne tanke er udbygget i: G. Theissen/Annette Merz: "The Delay of the Parousia as a Test Case for the Criterion of Coherence", Louvain Studies 32 (Louvain: Université Catholique Louvain 2007), 49-66. 
eskatologi og visdom i Jesus' forkyndelse. Eskatologien regner med en verden, som hører op, mens visdommen regner med, at verden og dens livsvenlige strukturer varer ved. Jesus har hørt hjemme i et visdomsmiljø. Men han tilsluttede sig Døberens eskatologiske budskab. Efter adskillelsen fra Døberen vendte han tilbage til sit udgangspunkt ${ }^{5}$ og udviklede vha. visdomstraditioner en præsentisk eskatologi, som siger, at den nye verden ikke kommer gennem fremtidige katastrofer, men derimod allerede skjult er ankommet i nutiden.

\section{b) Udviklingen fra forkyndelsen af frelse til en ny forkyndelse af dommen}

Også den anden udvikling i Jesus tankeverden kan langt bedre eftervises i Jesus' eskatologi end $i$ hans selvforståelse. Der er ingen tvivl om, at Jesus' budskab mødte modstand. Det er derfor sandsynligt, at han reaktiverede domsforkyndelsen. I så fald er han vendt tilbage til Døberens forkyndelse. Det kan forklare domsprædikenen mod de galilæiske byer og mod Jerusalem. Men det er mere vanskeligt at afgøre om Jesus pga. den voksende modstand imod ham regnede med en voldsom død, og det er endnu vanskeligere at eftervise, om han tilskrev sin død en forsonende virkning for alle. For alle bebudelser af hans død kan være vaticinia ex eventu, og alle soteriologiske tolkninger af hans død kan have været blevet til efter påske for at tilskrive hans grusomme død en mening trods alt.

Det er sikkert og vist, at hans død modsagde hans disciples forventninger. Alle flygtede (Mark 14,50). Fortællingen om Emmaus-disciplene (Luk 24,13-35) er bevis på deres skuffelse: Disciplene havde forventet Israels frelse (Luk 24,21), men de var nødt til at lære af den opstandne Kristus, at Messias' lidelser var nødvendige (Luk 24,26). Når allerede den jordiske Jesus skal have forudsagt lidelsens nødvendighed (Mark 8,31f), så drejer det sig sandsynligvis om senere indsigter, som retrospektivt blev tilskrevet denne. Men det er vel muligt, at Jesus har regnet med muligheden for en voldsom død. Ordene om profeternes voldsomme død kan have været sat i gang af Døberens skæbne og kan derfor være autentiske (Luk 11,49-51; 13,34-35). Hvis de først er blevet til efter påske, ville vi forvente, at Jesus' egen død var fremhævet i omtalerne af profeternes død. Men det er ikke tilfældet, tværtimod: Luk 13,34 klager over, at Jerusalem stener sine profeter, men Jesus korsfæstes. I lignelsen om de onde vinbønder (Mark 12,1-12) dræber forpagterne sønnen, dvs. Jesus. Men faktisk

5. Martin Ebner, Jesus - ein Weisheitslehrer. Synoptische Weisheitslogien im Traditionsprozess, HBS 15 (Freiburg: Herder 1998), 421-426: "Die Rückkehr des (apokalyptischen) Täuferschülers in die (weisheitliche) Heimat". 
bliver Jesus henrettet af romerne, ikke af vingårdens forpagtere (dvs. det jødiske aristokrati). Desuden bliver sønnen i lignelsen dræbt inden for vingården og derefter kastet ud af det. Men faktisk bliver Jesus ikke dræbt i Jerusalem, men uden for byen. Hans lig bliver begravet, og ikke kastet ud uden begravelse. Til trods for den allegorisering, som findes i denne lignelse, kan den have bevaret nogle træk fra en autentisk lignelse. ${ }^{6}$ Der mangler dog i alle disse udsagn en tolkning af Jesus' død som en sonende død for andre.

Først denne forestilling måtte med nødvendighed medføre en principiel forandring i forståelsen af frelsen. Indtil nu havde Jesus haft en tillid til Guds nåde, der accepterede de fortabte som en fader accepterer den fortabte søn. Denne accept forudsætter ikke, at nogen skal dø for syndernes skyld. Men kan man virkelig sige, at Jesus ved sit livs afslutning var kommet til den overbevisning, at han var nødt til at hengive sit liv for at frelse de mennesker, som afvisete ham?? forudsætte en formørkelse af hans Gudsbillede. Det ville desuden forudsætte, at ordene om Menneskesønnen, som skal hengive sit liv som løsesum for mange, er autentiske (Mark 10,45) og ligeså ordene ved det sidste måltid om blodet som udgydes for mange (Mark 14,24). Vi kan dog aldrig frigøre os fra den mistanke, at disse udsagn er retrospektive tolkninger af Jesus' død, som først blev til pga. påsketroen. Havde Jesus virkelig forberedt sine disciple på, at han måtte dø en voldsom død for menneskenes frelse, ville de ikke være flygtet så hovedkuls. Historien om Emmausdisciplene forudsætter, at disciplene ikke havde regnet med Jesus' voldsomme henrettelse, og at de først efter påske har fundet en mening og en tolkning af denne henrettelse vha. skriften. Det samme gælder disciplenes mangel på forståelse i Markusevangeliet. De kan ikke forstå, at Menneskesønnen og Messias skal lide, men nu er det - anderledes end i Emmaushistorien - i Markusevangeliet ikke den opstandne Kristus, men den jordiske Jesus, som belærer disciplene om sin lidelses nødvendighed.

Det skal understreges, at P. Bilde udvikler sin teori om messiasbevidsthedens udvikling hos Jesus med stor forsigtighed. Mange tanker er fuldstændigt uafhængige af denne teori. Bogen er skrevet i en åben ånd med sensibilitet for indvendinger. Det tydeligste budskab, som

6. Således James H. Charlesworth, Jesus within Judaism (New York: Doubleday 1988), $139 \mathrm{ff}$.

7. Jf. Lorenz Oberlinner, "Der Weg Jesu zum Leiden“, Jesus von Nazaret - Spuren und Konturen, red. Ludger Schenke m.fl. (Stuttgart: Kohlhammer 2004), 275318. 
læseren fornemmer, er det, at det betaler sig at diskutere den historiske Jesus. Bogen overbeviser ved sin kritiske holdning. Den indebærer nye tanker om tre aspekter: analogien mellem Jesus og andre tidshistoriske profeter, den messianske selvbevidsthed hos Jesus og udviklingen af Jesus' tanker om verden og om sig selv. Det er tre emner som skal diskuteres i fremtiden. Per Bilde har givet et vigtigt bidrag til denne debat. 